\title{
FINANCIAL LAW AND FINANCIAL SCIENCE: DEVELOPMENT AND INTERACTION
}

\author{
ELENA CHERNIKOVA
}

\begin{abstract}
The study provides a brief overview of the issues that take place in Russian and foreign scientific theory about the problems of development and interaction of financial science and financial law. The problems are presented through the prism of the interdependencies of economics and law, financial science and the theory of financial law. The author expresses hypotheses about the development of financial science and financial and legal theory, highlights the connections and differences between the subject, the conceptual-categorical apparatus, and the institutions that predetermine close relationships and dependencies at the interdisciplinary level.
\end{abstract}

Keywords: financial law; financial science; finance; public finance; interdisciplinary approach

Klíčová slova: finanční právo, finanční věda, finance, veřejné finance, interdisciplinární přístup

DOI: $10.14712 / 23366478.2020 .23$

\section{INTRODUCTION}

Nowadays, Russian and foreign scientific theory shows an increasing interest in researches related to issues of interaction and the relationship of financial law and financial science. The analysis of such studies indicates that there is no single trend, and scientific research is going on in different directions. At the same time, it should be noted that all researchers share one view in recognizing the objective reality of the interaction and the relationship of economics and law. Through this prism, we propose to consider individual problems of the modern development of financial science and financial law. Let us start with a brief overview of the issues that take place in Russian and foreign scientific theory on the problems of development and interaction of financial science and financial law. For decades now, Russian legal theory has been actively discussing the relationship between law and economy, and the development potential of constitutional and legal foundations for regulating economic relations. ${ }^{1}$ One of the results is the process

1 AVDIJSKIJ, V. - PAVLIKOV, S. On the Correlation of Economics and Law and Trends in Constitutional and Legal Regulation of Economic Relations. State and Law. 2014, No. 11, pp. 35-42. 
of formation of a new branch - the economic law of the Russian Federation. ${ }^{2}$ Herewith, economic law is presented as a mega-branch of Russian law, uniting and regulating the economy and economic relations. ${ }^{3}$ From the standpoint of financial law, we believe that the concept of the expediency and necessity of creating a new branch of Russian law - namely the economic law - is developing fairly within the scientific discussion about the idea of complex branches of law that arose in the late 1940s. According to a number of Russian researchers (Belikov E G., Rybakova S. V., Sokolova E. D., Khimicheva N. I.), the variety of economic phenomena cannot generate complex branches of law, but on the contrary, entails their comprehensive legislative regulation. The fact of the existence of complex social relations in the socio-economic sphere due to their polysynthesism does not form unity in the subject of legal regulation, rather, there is a need to combine material around a certain complex social relationship. ${ }^{4}$ Famous Russian jurist Nina Khimicheva noted that the complex nature is a characteristic feature for the branch of legislation, in contrast to the branch of law. ${ }^{5}$ The interaction of economics and law is indisputable, it exists and is recognized in scientific theory, but it cannot, and should not, lead to the formation of new branches of law. Law is a form of economic relations, their formalization, which has a certain vector of governing influence on an economic phenomenon. Law is capable of influencing economic, social and political processes, stimulating or oppressing. The sphere of finance, as public relations related to the creation, distribution, use of public money funds, is sufficiently regulated by financial law ${ }^{6}$, but at the same time, we observe the phenomenon of the coverage of this field of knowledge by two sciences - financial law and financial science.

\section{FINANCIAL LAW AND FINANCIAL SCIENCE: CONNECTIONS AND DIFFERENCES}

Nowadays, we observe both the phenomenon of diversification and the process of isolation of individual sciences. It is difficult to evaluate this process, and the purpose of the discussion is to study the relationships and dependencies that arise between financial science and financial law. We suggest starting by defining the concepts of these sciences, the subject, connections, similarities and differences. It should be noted that with regard to financial science and financial law, there is a growing need for their convergence in order to achieve advantages in scientific cooperation. This trend has been positively assessed in the scientific community, the appeal of lawyers and

2 ASHMARINA, E. - RUCHKINA, G. Economic Law of the Russian Federation (Subject and Method, System and Structure, Sources of Legal Regulation). State and Law. 2012, No. 8, pp. 32-34; ERSHOV, V. ASHMARINA E. - KORNEV, V. Economic Law of the Russian Federation: Monograph. M.: RGUP, 2017, pp. 15-19.

3 ASHMARINA, E. Economic Law, as a Micromodel of the System of Russian Law. Economic issues. 2015, No. 6, pp. 7-13.

4 RYBAKOVA, S. Complex relations as the basis for the emergence of complex entities in law (by the example of Financial Law). Leningrad Law Journal. 2013, No. 3 (33), pp. 179-185.

5 KHIMICHEVA, N. Financial Law. Moscow: Infra-M, 2012, p. 60.

6 SHOKHIN, S. Finansivie pravo - vremja peremen. Finansovoe pravo, 2014, No. 2, p. 3. 
economists to the analysis of the same social phenomena is a fruitful approach in terms of the effectiveness of research. ${ }^{7}$ Scientific cooperation between the two sciences seems to be natural, since the subject of both sciences is finance: in financial science - as a phenomenon, in the science of financial law - as a relationship. Financial phenomena and processes, their combination, financial system are obviously studied by such a scientific discipline as finance, which belongs to the field of economic sciences, and relations arising in connection with finances and financial phenomena are studied by financial law relating to legal sciences. Financial science (Finance), as a scientific discipline in European scientific theory, was singled out at the end of the 19 th century. ${ }^{8}$ Its research area had expanded over time, and especially as research became deeper, it led to the creation of sub-disciplines such as public finance, banking, insurance, and corporate finance. The subject of interest in finance as a science is mainly the financial motion, and above all, in the banking system, money circulation between various economic entities and their groups in the form of settlements, savings and reserves. ${ }^{9}$ The task of finance is to adjust the financial resources available to certain categories of business entities. ${ }^{10}$ In the Russian scientific doctrine, financial science was also formed in the second half of the 19th century, in 1841 the first textbook on financial science - "Theory of Finance" was prepared and published in the Russian language ${ }^{11}$ Financial science was a state science, its subjects were finance, primarily state, and state economy. Finance, as a term in scientific theory, has always had two dimensions: practical and theoretical. Practical is addressed to all subjects of the financial economy for which the regulation of the flow of goods and funds is a directive. In the theoretical dimension "... finance as a science explores and explains the economic content ... of material phenomena and processes, that is, the relationship between the cash flow and the distribution of financial resources, the financial flow and distribution of the resources of goods, material and non-material services and human labour". ${ }^{12}$ Thus, both Russian and foreign scientific theory have a similar historically established classic approach to the definition of the concept, essence and subject of financial science. Representatives of the Polish scientific doctrine further indicate that finance is associated with the creation and movement of money, with resources that exist in real terms, with their use and their obtaining in the future. ${ }^{13}$ The most important element pointing to the subject of financial science is the combination of cash flows both from the side of their collection into revenues, and from the side of expenditures with specific goals. ${ }^{14}$ This view is connected with the fundamental statement concerning the functional aspects of science, and the indication that it gives "... the economy and financial policy some knowledge about the efficient use of money in managing the national

\footnotetext{
7 HABRIEVA, T. Economic and Legal Analysis: a methodological approach. Journal of Russian Law, 2010, No. 12 , pp. 7-12.

8 FLEJTERSKI, S. Fundamentals of Financial Theory. Elements of a Comparative Analysis. Szczecin: Economics, 2006, p. 51.

9 FEDOROWICZ, Z. Fundamentals of financial theory. Warsaw: Poltext, 1991, p. 8.

10 BOLLAND, C. Introduction to finance. Warsaw: Polish Economic Publishing House, 1979, p. 6.

11 GORLOV, I. Theory of Finance. Kazan, 1841.

12 BOLLAND, C. Introduction to Finance. Warsaw: Polish Economic Publishing House, 1979, p. 10.

13 OSTASZEWSKI, J. Finance. Warsaw: Difin, 2007, p.16.

14 SZCZESNY, B. Finances. Lecture plan. Warsaw: Difin, 2009, p. 13.
} 
economy ....". ${ }^{15}$ More often, the relationship between finance and financial law is discussed and investigated through the prism of public finance, and most western experts emphasize that "nowadays, the problems of public finance are a conglomerate of legal economic and political phenomena, therefore, attracting research to economic aspects cannot fully the same time, a correct view of reality ...". ${ }^{16}$ P. M. Gaudemet and J. Molinier were the forerunners of this view. ${ }^{17}$ Polish researchers emphasize that public finance was a discipline in which, when researching, they tried to balance economic and legal aspects. ${ }^{18}$ The problem associated with this issue comes down to the uniqueness and clarity of legal provisions that form the basis for the efficient use of financial resources. For example, in the Polish scientific literature some disadvantages of financial law were noted: excessive casuistics of provisions, their excessive detail and high frequency of changes. Indeed, the imperfection of the law has wide consequences for the possibilities of maintaining a rational financial economy, which requires stability and prospects for its development. In such circumstances, coercion of the legislature is mandatory. ${ }^{19}$ In the Russian scientific legal doctrine, Yuri Tikhomirov had been writing on the importance of regulating economic relations by law: “... the law must and really begins to play a qualitatively different role - to an ever greater extent, have a stimulating effect on economic, political and social processes. And the law is called to take a leading place in the legal system". ${ }^{20}$ In the Russian financial and legal doctrine, financial law by its nature belongs to the category of disciplines of state studies, as it is depicted by Olga Gorbunova. There is no better way to rule a state than to manage with money. By regulating and directing cash flows, the state contributes to the development of certain areas of the economy or, conversely, reduces and can even completely curtail individual activities. Finance, in a figurative expression, is the circulatory system of the state. ${ }^{21}$ Financial law, like a surgeon's scalpel, requires laser precision and a neurosurgical approach. The consequences of financial law action, or the risks of public administration without it, are quite high. Due to the large volume of financial legislation, and norm-setting activity, there is a problem of interpretation which is important both for financial science and for the science of financial law. In this context, an important element in the process of creating a law is its form with which has no need to be changed often. This is due to the fact that frequent amendments lead to chaos in the legal system. In this case, the quality of the law does not improve, this leads to the fact that the law becomes dead. ${ }^{22}$ However, the disadvantages

15 BOLLAND, C. Introduction to Finance. Warsaw: Polish Economic Publishing House, 1979, pp. 6-10.

16 KOSIKOWSKI, C. - RUSKOWSKI, E. Public Finances and Financial Law. Warsaw: Publishing House ABC, 2003, p. 128.

17 GAUDEMET, P. M., MOLINIER, J. Public Finance. Warsaw: Polish Economic Publishing House, 2000, p. 17.

18 KOSIKOWSKI, C. - RUSKOWSKI, E. Public Finances and Financial Law. Warsaw: Publishing House ABC, 2003, p. 128-129.

19 DEBOWSKA-ROMANOWSKA, T. Trends in the creation of legal and financial provisions and their impact on the understanding of organizational (systematic) law in Poland. In: Pomorska, A. et al. (eds). In the Circle of Financial Law and Public Finance. Lublin: UMCS, 2005, p. 78-83.

20 TIKHOMIROV, Yu. Law. Incentives. Economics. Moscow: Legal literature, 1989, p. 4-5.

21 GORBUNOVA, O. Selected works. Moscow: RGUP, 2017, p. 458-470.

22 CHOJNA-DUCH, E. The instrumental use of law in litigation in the light of amendments to the Law on Public Finances of 2004. In: Pomorska, A. et al. (eds). In the Circle of Financial Law and Public Finance. Lublin: UMCS, 2005, p. 70. 
of financial law do not detract from its constructive role. Another problem was highlighted in the Russian financial and legal doctrine - in the science of Russian financial law in recent years the concept of "economic and legal categories" has appeared. Is this desirable, or the undesirable effect of the interaction of economic and legal science. In this regard, it is appropriate to recall the statement of Tsypkin that the representatives of the science of financial law should use "ready-made economic provisions developed by the science of finance, without turning into an economic and legal science". ${ }^{23}$ In this part it is important to note the significant contribution to the development of the theory of financial law of Czech researchers. In the monograph Theory of financial law and financial science much attention is paid to the development of definitions of concepts, categories, an in-depth analysis of the conceptual and categorical foundations, principles, sources of financial law, the financial and legal doctrine is comprehensively presented and the directions for its development are given. Thus, M. Karfikova notes the importance of the conceptual apparatus in scientific theory: "each branch of law has its main categories and institutions, and financial law is no exception. In financial regulation, these categories can be described as financial categories. Now financial activities, financial relations, finance and financial government control can be considered as the main financial categories". ${ }^{24}$ Another problem that exists in both Russian and foreign scientific doctrine comes down to whether financial law and finance can be regarded as scientific disciplines without taking into account their internal division. The Polish researcher A. Drwillo examines separately: banking law, customs law, budget law, and also tax law and the law of territorial self-government. ${ }^{25}$ A scientific discussion about the necessity and possibilities of dividing financial law into several separate branches in the Russian scientific doctrine began at the end of the 20th century, and contains radical proposals. ${ }^{26}$ At the same time, wider sub-disciplines are applied in the science of finance in the following areas: the banking system, the public finance system, the financial insurance system, and corporate finance or business finance. ${ }^{27}$ The raised problem of the internal diversification of financial law and finance aimed to draw attention to their wide field, and the need to link individual sub-disciplines of finance with the sub-sectors of financial law, which formally regulate the economy in certain areas. At the same time, we must not forget that financial law is a part of the general system of law, and finance is a part of the economy, which determines the diversification of research activities based on the analysis of financial law and economic accounting in the science of finance. It should be recalled that this problem was raised in the Russian financial and legal doctrine - "The rules of the financial economy, invested in well-known legislative norms, will be financial legislation, or financial law. A theoretical study of all these basic concepts, that is, finance, financial economy, financial law, constitutes financial

\footnotetext{
23 TSYPKIN, S. Public Revenues of the USSR. Legal issues. Moscow: Legal literature, 1973, pp. 77-120.

24 KARFIKOVA, M. et al. Teorie finančního práva a finanční vědy. Praha: Wolters Kluwer, pp. 3-5.

25 DRWILLO, A. Theory of finance and financial law. Warsaw: Lex a Wolters Kluwer Business, 2011, pp. 237, 273, 310, 389, 554 .

26 SOKOLOVA, E. The problem of the formation of new branches of Russian law. Financial right, 2017, No. 5, pp. 9-13.

27 OWSIAK, S. Finance. Warsaw: Polish Economic Publishing House, 2015, p. 248-273.
} 
science." 28 In modern Russian financial law, it is noted that the creation of the theory of public finance and their definition are, first of all, the task of not legal, but economic science. Unfortunately, in modern financial science there is neither a clear definition of public finance, nor a theory of this segment of financial relations. Thus, to date, there is no synchronicity in research between financial or financial and legal science. In any case, it is worth emphasizing that the development of the problem of public finance at the level of the tasks of financial science and the science of financial law could be very useful for both sciences. ${ }^{29}$

\section{CONCLUSION}

One of the goals of this discussion was to systematize knowledge of the relationship between financial science and financial law in the context of interdependencies and relationships, as well as to determine the reasons for this and, finally, to identify some possibilities for making changes. Such relationships and relationships are indisputable, their assessment is also important in terms of the impacts they cause. The effects of this interaction can be positive (we can even call them desirable) and negative (undesirable). The above discussion leads to the conclusion that scientific disciplines, such as finance and financial law are formally isolated, and are correlated accordingly with such areas of knowledge as economics and law. In their essence, financial science and financial law cannot be isolated from each other, but at the same time, the process of their deeper separation still seems to us an inevitable and objective phenomenon. The reason for this is the ever-growing process of cognition, the expansion of the diversity of social phenomena and, the emergence of the need for an ever wider and more detailed study by each science of its subject. Deep knowledge is possible within the framework of existing sciences and makes possible a more complete presentation of all knowledge and, therefore, their effective use. In any case, the main goal of any science is always the search for truth, pure knowledge, and the need for scientific cooperation between financial science and financial law is obvious. In our opinion, cooperation should be expanded both interdisciplinary and at the institutional level, between universities, organizations, including international. In this regard, it will be necessary to increase the volume of joint research using an interdisciplinary approach to studying the practice of financial and economic phenomena. It would be useful in this regard to create a monographic textbook for students of legal and economic specialties.

Prof. Dr. Elena Chernikova

Russian Academy of National Economy and Public Administration under the President of the Russian Federation, Moscow, Russia

ev.chernikova@igsu.ru

8 LEBEDEV, V. Financial Law. Moscow, 2000. p. 36

29 KARASEVA, M. V. (ed.) Actual problems of financial and tax law: a textbook. Moscow: Prospect, 2020, pp. 10-12. 